\begin{tabular}{|} 
Ambiente \& Água - An Interdisciplinary Journal of Applied Science \\
ISSN 1980-993X - doi:10.4136/1980-993X \\
www.ambi-agua.net \\
E-mail: ambi.agua@gmail.com
\end{tabular}

\title{
Lactase production by Saccharomyces fragilis IZ 275 using different carbon sources
}

\author{
ARTICLES doi:10.4136/ambi-agua.2474
}

Received: 24 Sep. 2019; Accepted: 19 Feb. 2020

\begin{abstract}
Alessandra Bosso $^{1 * i D}$; Adriana Aparecida Bosso Tomal ${ }^{2}$;
Lucas Caldeirão Miranda ${ }^{3}$; Josemeyre Bonifácio da Silva1 ${ }^{1}$; Hélio Hiroshi Suguimoto ${ }^{1}$; Raul Jorge Hérmaz Castro-Gomez ${ }^{2}$ (D)
\end{abstract}

\author{
${ }^{1}$ Mestrado em Ciência e Tecnologia de Leite e Derivados. Universidade Pitágoras (UNOPAR), \\ Rua Marselha, n 591, CEP: 86041-140, Londrina, PR, Brazil. \\ E-mail: josibonifacio0576@gmail.com, helio.suguimoto@unopar.br \\ ${ }^{2}$ Departamento de Ciência e Tecnologia de Alimentos. Centro de Ciências Agrárias. Universidade Estadual de \\ Londrina (UEL), Rodovia Celso Garcia Cid (PR 445), Km 380, Caixa Postal: 10.011, CEP: 86057-970, \\ Londrina, PR, Brazil.E-mail: adriana_bosso@yahoo.com.br, rcastrog@yahoo.com \\ ${ }^{3}$ Departamento de Ciência de Alimentos. Faculdade de Engenharia de Alimentos. Universidade Estadual \\ Campinas (UNICAMP), Rua Monteiro Lobato, n 80, CEP: 13083-862, Campinas, SP, Brazil. \\ E-mail: lcrmiranda@gmail.com \\ *Corresponding author. E-mail: alessandrabosso@yahoo.com.br
}

\begin{abstract}
This study sought to create a better fermentation medium to maximize lactase production by Saccharomyces fragilis IZ 275 using different carbon sources, including reconstituted powdered cheese whey. A factorial design $2^{4}$ was applied to evaluate the significant effects of variables which compose the fermentation medium. Then, a steepest descent-ascent design was applied to obtain the maximum activity. A Rotational Central Composite Design (RCCD) $2^{4}$ was made to optimize the fermentation medium. We verified that the cheese whey, a by-product of the dairy industry, can be employed as an excellent fermentation medium by yeast, within the bioeconomy concept and used by the dairy industry as product with additional value. The employed methodology is an efficient tool in the optimization process for $\beta$-galactosidase production. In the optimized fermentation medium, the maximum production of $\beta$-galactosidase (54.68 U/mL) by $S$. fragilis IZ 275 is obtained with $14 \mathrm{~g} / \mathrm{L}$ sucrose, $17.7 \mathrm{~g} / \mathrm{L}$ reconstituted powdered cheese whey, $5.14 \mathrm{~g} / \mathrm{L}$ yeast extract and $8.85 \mathrm{~g} / \mathrm{L}$ peptone.
\end{abstract}

Keywords: $\beta$-galactosidase, Cheese whey, environmental damage.

\section{Produção de lactase por Saccharomyces fragilis IZ 275 usando diferentes fontes de carbono}

\section{RESUMO}

O presente trabalho teve como objetivo estudar a melhor composição do meio de fermentação para máxima produção de lactase por Saccharomyces fragilis IZ 275 usando diferentes fontes de carbono incluindo o soro de queijo em pó reconstituído. Primeiramente, um delineamento fatorial $2^{4}$ foi aplicado para verificar dentre as variáveis estudadas as que apresentavam efeito significativo. Logo após, foi aplicado um delineamento de máxima inclinação ascendente e máxima inclinação descendente para obter a máxima atividade. Para 
otimizar o meio de fermentação, foi então, realizado um delineamento Composto Central Rotacional (DCCR) $2^{4}$. Foi observado que o soro de queijo, um subproduto da indústria de lacticínios, e altamente poluidor para o meio ambiente, pode ser empregado como excelente meio de fermentação por leveduras, dentro do conceito de bioeconomia com valor agregado. $\mathrm{O}$ emprego da metodologia é uma ferramenta eficiente para otimizar o processo de produção da $\beta$-galactosidase. No meio de fermentação otimizado, a máxima produção de $\beta$-galactosidase (54,68 U/mL) por S. fragilis IZ 275 é obtida com $14 \mathrm{~g} / \mathrm{L}$ sacarose, 17,7 g/L soro de queijo em pó reconstituído, $5,14 \mathrm{~g} / \mathrm{L}$ extrato de levedura e $8,85 \mathrm{~g} / \mathrm{L}$ peptona.

Palavras-chave: $\beta$-galactosidase, impacto ambiental, soro de queijo.

\section{INTRODUCTION}

$\beta$-D-galactosidase (EC 3.2.1.23; $\beta$-D-galactoside galactohydrolase) or lacatase has several applications in the food industry (Jones et al., 2017). It is an intracellular enzyme that hydrolyzes lactose, a disaccharide present in milk and dairy products, into its two monosaccharides units, galactose and glucose, which are easily absorbed in most organisms, including humans (Anisha, 2017; Panesar et al., 2006). Some people are lactose intolerant and cannot digest lactose properly due to an inactive intestinal lactase enzyme. Common symptoms of lactose intolerance are intestinal-dysfunction gas, abdominal pain, and diarrhea. The sugar is found in mammalian milk at a concentration of 3-8\% (w/v), and has low solubility and sweetness. (Perini et al., 2013; Cardoso et al., 2017).

One of the main sources for the production of lactase are yeasts (Mlichová and Rosenberg, 2006) by the submerged fermentation process (Anisha, 2017). Several factors influence the production of lactase, such as temperature, $\mathrm{pH}$, incubation time and fermentation medium. The optimization of the fermentation medium is critical for $\beta$-galactosidase production (Jones et $a l ., 2017)$. and some works have described these factors that influence the $\beta$-galactosidase production (Karlapudi et al., 2018; Venkateswarulu et al., 2017). However, the best composition of fermentation medium for maximizing the lactase production by yeast has not been yet developed.

Cheese whey produced during cheese-making or during the coagulation of milk casein process presents as principal components, lactose (70-72\% of the total solids), whey proteins (8\%-10\%) and minerals (12-15\%) (Yadav et al., 2015). Over the last few decades, the dairy industry has explored different alternatives to exploit the valuable components of cheese whey. The world production of whey (El-Tanboly et al., 2017) is estimated to be around 180 to $190 \mathrm{x}$ $10^{6}$ ton / year, and causes serious socio-economic and environmental problems, since much of this amount is discarded in the environment. Furthermore, Lopes et al. (2018) found that, in comparison to domestic sewage, cheese whey can be 100 times more polluting. One alternative to help remediate these problems would be the application of cheese whey as the fermentation medium for lactase production by microorganisms within the concept of circular economy or bioeconomy (Ranta et al., 2018; López-Gómez et al., 2019). This will promote the integration of economic activities and environmental wellbeing in a sustainable way.

Considering these aspects, we studied the creation of a better composition of fermentation medium to maximize lactase production by Saccharomyces fragilis IZ 275 using different carbon sources, including reconstituted powdered cheese whey.

\section{MATERIAL AND METHODS}

\subsection{Microorganism and inoculum}

Saccharomyces fragilis IZ 275 yeast was used for the study and collected in the Collection of Tropical Cultures (WDCM 69885 number). The yeast was maintained in tubes containing 
PDA (Potato Dextrose Agar, Acumedia) and stored at $4{ }^{\circ} \mathrm{C}$, and was reactivated in a medium containing (w/v) malt extract $(2 \%)$ yeast extract $(0.5 \%)$ autoclaved at $121^{\circ} \mathrm{C}$ for $15 \mathrm{~min}$ and then incubated at $30^{\circ} \mathrm{C}$ for $48 \mathrm{~h}$ on an orbital shaker (Tecnal $\left.{ }^{\circledR}, \mathrm{TE}-420\right)$. The inoculum was performed by using a Neubauer chamber at a count of $1 \times 10^{7}$ cells $/ \mathrm{mL}$. An inoculum concentration of $10 \% \mathrm{v} / \mathrm{v}$ was used in relation to the culture medium.

\subsection{Extraction and analysis of $\beta$-galactosidase}

Samples of $80 \mathrm{~mL}$ fermentation medium were centrifuged (Eppendorf centrifuge 5804R, Germany) under conditions of $27,200 \times \mathrm{g}, 4^{\circ} \mathrm{C}$ for $5 \mathrm{~min}$. The supernatant was resuspended in $0.1 \mathrm{M}$ phosphate buffer, $\mathrm{pH}$ 6.6, and centrifuged again under the above conditions. The new precipitate was solubilized in $10 \mathrm{~mL}$ of the same buffer, to which $0.2 \mathrm{~mL}$ of chloroform was added. This mixture was incubated at $37^{\circ} \mathrm{C}$ under agitation of $150 \mathrm{rpm}$ for $17 \mathrm{~h}$. The suspension was then centrifuged and the supernatant used to determine the enzymatic activity. The enzymatic activity was determined using the o-nitrophenyl- $\beta$-D-galactopyranoside substrate (ONPG) following the methodology described in the Food Chemical Codex (National Academy of Sciences, 1996) with some modifications. The ONPG $(1.25 \mathrm{mM})$ substrate dissolved in 0.05 $\mathrm{M}$ sodium phosphate buffer ( $\mathrm{pH}$ 7.0) was used. The amount of substrate and enzyme used were $2 \mathrm{~mL}$ and $0.5 \mathrm{~mL}$, respectively. At the time zero, $0.5 \mathrm{~mL}$ of enzyme solution was added to the ONPG solution and incubated for $5 \mathrm{~min}$. The assay was stopped by the addition of $0.5 \mathrm{~mL}$ sodium carbonate $1 \mathrm{M}$, and the absorbance was determined in spectrophotometer (Biochrom libra S22 Cambridge England) at $420 \mathrm{~nm}$. One enzymatic unit was defined as the quantity of enzyme that would liberate $1 \mathrm{mM}$ of o-nitrophenol from ONPG per minute under the assay conditions. Enzymatic unit was calculated using the following Equation 1:

$$
\text { Unit } / \mathrm{mL}=\mathrm{A} \times \text { dilution factor } / \varepsilon \times \text { time } \mathrm{x} \text { enzyme solution }
$$

Where A was the absorbance at $420 \mathrm{~nm}$, dilution factor was the fold dilution of the enzyme solution, enzyme solution was the amount of enzyme $(\mathrm{mL})$ undergoing the reaction, $\varepsilon$ was the extinction coefficient (determined from the o-nitrophenol standard curve) and time was the incubation time (15 min).

\subsection{Experiment 1: screening experiments to investigate the composition of medium fermentation}

First, initial experiments were performed to evaluate the significant effects of variables which compose the fermentation medium used for $\beta$-galactosidase production by Saccharomyces fragilis IZ 275 yeast. A factorial design $2^{4}$ was applied with eight variables and three replicates at the central point totaling 19 assays. The coded independent variables $\left(\mathrm{x}_{1}, \mathrm{x}_{2}\right.$, $\mathrm{x}_{3}, \mathrm{X}_{4}, \mathrm{X}_{5}, \mathrm{X}_{6}, \mathrm{X}_{7}$ and $\left.\mathrm{x}_{8}\right)$ and uncoded variables $\left(\mathrm{X}_{1}=\mathrm{g} / \mathrm{L}\right.$ lactose, $\mathrm{X}_{2}=\mathrm{g} / \mathrm{L}$ sucrose, $\mathrm{X}_{3}=\mathrm{g} / \mathrm{L}$ glucose, $X_{4}=\mathrm{g} / \mathrm{L}$ cheese whey, $X_{5}=\mathrm{g} / \mathrm{L}$ yeast extract, $X_{6}=\mathrm{g} / \mathrm{L}$ peptone, $X_{7}=\mathrm{g} / \mathrm{L} \mathrm{MgSO}_{4}$ and $\mathrm{X}_{8}=\mathrm{g} / \mathrm{L} \mathrm{K}_{2} \mathrm{HPO}_{4}$ ) are shown in Table 1 with their variation levels.

The fermentation media were run in $250 \mathrm{~mL}$ Erlenmeyer flasks containing $100 \mathrm{~mL}$ of each, incubated on the orbital shaker (Tecnal, TE-420) at $180 \mathrm{rpm}$ and with $\mathrm{pH}$ initial 6.8 , at $30^{\circ} \mathrm{C}$ temperature for $72 \mathrm{~h}$ according to the literature (Kumar et al., 2012). The $\beta$-galactosidase production was evaluated in terms by $\beta$-galactosidase activity and its response function as follows: $Y_{1}(\beta$-galactosidase activity, $U / \mathrm{mL})$. The model equation was as follows: $Y_{1}=\beta_{0}+$ $\beta_{1} \mathrm{X}_{1}+\beta_{2} \mathrm{X}_{2}+\beta_{3} \mathrm{X}_{3}+\beta_{4} \mathrm{X}_{4}+\beta_{5} \mathrm{X}_{5}+\beta_{6} \mathrm{X}_{6}+\beta_{7} \mathrm{X}_{7+} \beta_{8} \mathrm{X}_{8}+\mathrm{e}$

Where $\mathrm{Y}_{1}$ (response function), $\mathrm{x}_{1}, \mathrm{x}_{2}, \mathrm{x}_{3}, \mathrm{x}_{4}, \mathrm{x}_{5}, \mathrm{x}_{6}, \mathrm{x}_{7}$ and $\mathrm{x}_{8}$ (coded variables), $\beta$ (estimated coefficients for each term of the response surface model). The response functions ( $\left.\mathrm{Y}_{1}\right)$ were used to perform regression analyses and analysis of variance (ANOVA) for the regression and were performed using STATISTICA 7.0 software (StatSoft Inc., 2007). 
Table 1. Independent variables and levels of variation in factorial design $2^{4}$.

\begin{tabular}{lccc}
\hline & \multicolumn{3}{c}{ Levels } \\
\cline { 2 - 4 } Independent Variables & $\mathbf{- 1}$ & $\mathbf{0}$ & $\mathbf{1}$ \\
\hline Lactose $(\mathrm{g} / \mathrm{L}) \mathbf{X}_{\mathbf{1}}$ & 1 & 5.5 & 10 \\
Sucrose (g/L) $\mathbf{X}_{\mathbf{2}}$ & 1 & 5.5 & 10 \\
Glucose (g/L) $\mathbf{X}_{\mathbf{3}}$ & 1 & 5.5 & 10 \\
Cheese whey $(\mathbf{g} / \mathrm{L}) \mathbf{X}_{\mathbf{4}}$ & 1 & 5.5 & 10 \\
Yeast extract (g/L) $\mathbf{X}_{\mathbf{5}}$ & 0.5 & 2.75 & 5 \\
${\text { Peptone }(\mathrm{g} / \mathrm{L}) \mathbf{X}_{\mathbf{6}}}_{\mathbf{M g S O}_{\mathbf{4}}(\mathbf{g} / \mathbf{L}) \mathbf{X}_{\mathbf{7}}}$ & 0.5 & 2.75 & 5 \\
$\mathbf{K}_{\mathbf{2}} \mathbf{H P O}_{\mathbf{4}}(\mathbf{g} / \mathbf{L}) \mathbf{X}_{\mathbf{8}}$ & 0.5 & 2.75 & 5 \\
\hline
\end{tabular}

\subsection{Experiment 2: Method of steepest ascent-descent design to investigate the maximum increase of $\beta$-galactosidase activity}

From the results of factorial design and to obtain the maximum increase of $\beta$-galactosidase activity, a steepest descent-ascent design was applied (Montgomery, 2011). The independent variables were stabilized as follows: sucrose and cheese whey ranged from 6 to $16 \mathrm{~g} / \mathrm{L}$; yeast extract, peptone and $\mathrm{MgSO}_{4}$ ranged from 2 to $8 \mathrm{~g} / \mathrm{L}$; the variables lactose and glucose ranged from null to $10 \mathrm{~g} / \mathrm{L}$ and $\mathrm{K}_{2} \mathrm{PHO}_{4}$ ranged from null to $5 \mathrm{~g} / \mathrm{L}$ (Table 2).

\subsection{Experiment 3: Rotational Central Composite Design (RCCD) $2^{4}$ to optimize the medium fermentation to $\beta$-galactosidase production and model validation}

From the results of steepest ascent-descent design and to optimize the fermentation medium for $\beta$-galactosidase production, a third experiment was performed. In this third step, a Rotational Central Composite Design (RCCD) $2^{4}$ was applied with two central points and eight axial points, for orthogonal, totaling 26 assays. The coded independent variables $\left(\mathrm{x}_{1}, \mathrm{x}_{2}, \mathrm{x}_{3}, \mathrm{x}_{4}\right)$ and uncoded variables $\left(\mathrm{X}_{1}=\right.$ sucrose $\mathrm{g} / \mathrm{L}, \mathrm{X}_{2}=$ cheese whey $\mathrm{g} / \mathrm{L}, \mathrm{X}_{3}=$ yeast extract $\mathrm{g} / \mathrm{L}$ and $\mathrm{X}_{4}$ $=$ peptone $\mathrm{g} / \mathrm{L})$ are shown in Table 3 with their variation levels. The coded independent variables $\left(\mathrm{x}_{5}, \mathrm{X}_{6}, \mathrm{X}_{7}, \mathrm{x}_{8}\right)$ and uncoded variables $\left(\mathrm{X}_{5}=\right.$ lactose $\mathrm{g} / \mathrm{L}, \mathrm{X}_{6}=$ glucose $\mathrm{g} / \mathrm{L}, \mathrm{X}_{7}=\mathrm{MgSO}_{4}$ $\mathrm{g} / \mathrm{L}$ and $\mathrm{X}_{8}=\mathrm{K}_{2} \mathrm{HPO}_{4}=\mathrm{g} / \mathrm{L}$ ) that did not show significance in the factorial design were stabilized according to the steepest ascent-descent design (Table 2).

For each assay, the fermentation media were run in $250 \mathrm{~mL}$ Erlenmeyer flasks containing $100 \mathrm{~mL}$ of each, incubated on the orbital shaker (Tecnal, TE-420) at $180 \mathrm{rpm}$ and with $\mathrm{pH}$ initial 6.8 at $30^{\circ} \mathrm{C}$ temperature for $72 \mathrm{~h}$. $\beta$-galactosidase production was evaluated in terms of $\beta$ galactosidase activity by its response function as follows: $\mathrm{Y}_{2}(\beta$-galactosidase activity, $\mathrm{U} / \mathrm{mL})$. The model equation was as follows: $Y_{2}=\beta_{0}+\beta_{1} x_{1}+\beta_{2} x_{2}+\beta_{3} X_{3}+\beta_{4} X_{4}+\beta_{11} x_{1}^{2}+\beta_{22} x_{2}^{2}+\beta_{33}$ $\mathrm{x}_{3}^{2}+\beta_{44} \mathrm{x}_{4}^{2}+\beta_{12} \mathrm{x}_{1} \mathrm{x}_{2}+\beta_{13} \mathrm{x}_{1} \mathrm{x}_{3}+\beta_{14} \mathrm{x}_{1} \mathrm{x}_{4}+\beta_{23} \mathrm{x}_{2} \mathrm{x}_{3}+\beta_{24} \mathrm{x}_{2} \mathrm{x}_{4}+\beta_{34} \mathrm{x}_{3} \mathrm{x}_{4}+\mathrm{e}$.

Where $\mathrm{Y}_{2}$ (response function), $\mathrm{x}_{1}, \mathrm{x}_{2}, \mathrm{x}_{3}$ and $\mathrm{x}_{4}$ (coded variables), $\beta$ (estimated coefficients for each term of the response surface model) and $\mathrm{e}=$ pure error. The response functions $\left(\mathrm{Y}_{2}\right)$ were used to perform regression analyses and analysis of variance (ANOVA) for the regression. The equation model was fitted to experimental data to yield the proposed model. Response surface graphs were generated. All executed analysis and response surfaces were performed with STATISTICA 7.0 software (StatSoft Inc., 2007). After response surface analysis for maximum $\beta$-galactosidase activity, the proposed model was validated by performing new assays in triplicate. The results $\left(\mathrm{Y}_{\text {exp. }}\right)$ were compared with the estimated response $\left(\mathrm{y}^{\wedge}{ }_{1}\right)$ by Student's t-test $(\mathrm{p}<0.05)$. 
Table 2. Steepest ascent-descent design to the maximum increase in terms of $\beta$-galactosidase production.

\begin{tabular}{|c|c|c|c|c|c|c|c|c|c|}
\hline Assays & $\begin{array}{l}\text { Sucrose } \\
\text { g/L }\end{array}$ & $\begin{array}{c}\text { Whey Cheese } \\
\text { g/L }\end{array}$ & $\begin{array}{c}\text { Yeast extract } \\
\mathrm{g} / \mathrm{L}\end{array}$ & Peptone g/L & $\begin{array}{c}\mathrm{MgSO}_{4} \\
\mathrm{~g} / \mathrm{L}\end{array}$ & Lactose $\mathrm{g} / \mathrm{L}$ & Glucose $\mathrm{g} / \mathrm{L}$ & $\begin{array}{c}\mathrm{K}_{2} \mathrm{PO}_{4} \\
\mathrm{~g} / \mathrm{L}\end{array}$ & $\begin{array}{c}\beta \text {-galactosidase activity } \\
\mathrm{U} / \mathrm{mL}\end{array}$ \\
\hline 1 & 6 & 6 & 2 & 2 & 2 & 10 & 10 & 5 & 17.21 \\
\hline 2 & 8 & 8 & 4 & 4 & 4 & 10 & 10 & 5 & 34.84 \\
\hline 3 & 12 & 12 & 6 & 6 & 6 & 10 & 10 & 5 & 26.98 \\
\hline 4 & 14 & 14 & 7 & 7 & 7 & 10 & 10 & 5 & 39.81 \\
\hline 5 & 16 & 16 & 8 & 8 & 8 & 10 & 10 & 5 & 27.03 \\
\hline 6 & 6 & 6 & 2 & 2 & 2 & 1 & 1 & 0.5 & 1.57 \\
\hline 7 & 8 & 8 & 4 & 4 & 4 & 1 & 1 & 0.5 & 13.51 \\
\hline 8 & 12 & 12 & 6 & 6 & 6 & 1 & 1 & 0.5 & 19.61 \\
\hline 9 & 14 & 14 & 7 & 7 & 7 & 1 & 1 & 0.5 & 23.36 \\
\hline 10 & 16 & 16 & 8 & 8 & 8 & 1 & 1 & 0.5 & 20.84 \\
\hline 11 & 6 & 6 & 2 & 2 & 2 & 5.5 & 5.5 & 2.75 & 10.67 \\
\hline 12 & 8 & 8 & 4 & 4 & 4 & 5.5 & 5.5 & 2.75 & 18.61 \\
\hline 13 & 12 & 12 & 6 & 6 & 6 & 5.5 & 5.5 & 2.75 & 16.25 \\
\hline 14 & 14 & 14 & 7 & 7 & 7 & 5.5 & 5.5 & 2.75 & 18.61 \\
\hline 15 & 16 & 16 & 8 & 8 & 8 & 5.5 & 5.5 & 2.75 & 13.46 \\
\hline 16 & 6 & 6 & 2 & 2 & 2 & null & null & null & 2.46 \\
\hline 17 & 8 & 8 & 4 & 4 & 4 & null & null & null & 7.09 \\
\hline 18 & 12 & 12 & 6 & 6 & 6 & null & null & null & 13.29 \\
\hline 19 & 14 & 14 & 7 & 7 & 7 & null & null & null & 14.12 \\
\hline 20 & 16 & 16 & 8 & 8 & 8 & null & null & null & 17.39 \\
\hline
\end{tabular}

Table 3. Independent variables and levels of variation in RCCD $2^{4}$.

\begin{tabular}{lccccc}
\hline & \multicolumn{5}{c}{ Levels } \\
\cline { 2 - 6 } Independent Variables & -1.48 & -1 & 0 & 1 & 1.48 \\
\hline Sucrose (g/L) X & 10.29 & 11.5 & 14 & 16.5 & 17.70 \\
Cheese Whey (g/L) X & 10.29 & 11.5 & 14 & 16.5 & 17.70 \\
Yeast Extract (g/L) X & 5.14 & 5.75 & 7 & 8.25 & 8.85 \\
Peptone (g/L) X & 5.14 & 5.75 & 7 & 8.25 & 8.85 \\
\hline
\end{tabular}




\section{RESULTS AND DISCUSSION}

\subsection{Factorial design $2^{4}$ to investigate the composition of fermentation medium}

The first experiment was performed using a factorial design of $2^{4}$ for evaluating the effects of significant variables which compose the fermentation medium of Saccharomyces fragillis IZ 275 during $\beta$-galactosidase production. According to ANOVA and regression analysis, only the independent variables $\mathrm{X}_{4}$ (cheese whey) and $\mathrm{X}_{5}$ (yeast extract) were shown to have a significant effect on the response function $\mathrm{Y}_{1}$ ( $\beta$-galactosidase activity, $\mathrm{U} / \mathrm{mL}$ ). None of the other independent variables had a significant effect and the coefficient of determination $\left(\mathrm{R}^{2}\right)$ was 0.75 . The proposed model could be described as follows:

$\mathrm{Y}_{1}=6.23+5.58 \mathrm{x}_{4}+8.72 \mathrm{x}_{5}$. Thus, the $\beta$-galactosidase activity was $20.53 \mathrm{U} / \mathrm{mL}$. The highest $\beta$-galactosidase activity $\left(\mathrm{Y}_{1}\right)$ was obtained in the assay $16\left(\mathrm{Y}_{1}=28.42 \mathrm{U} / \mathrm{mL}\right)($ Table 4$)$ when the independent variables were shown in the maximum levels. This correspond to using $\mathrm{X}_{1}$ (lactose); $\mathrm{X}_{2}$ (sucrose); $\mathrm{X}_{3}$ (glucose) and $\mathrm{X}_{4}$ (cheese whey) at a concentration of $10 \mathrm{~g} / \mathrm{L}$ and while using $\mathrm{X}_{5}$ (yeast extract), $\mathrm{X}_{6}$ (peptone), $\mathrm{X}_{7}\left(\mathrm{MgSO}_{4}\right)$ and $\mathrm{X}_{8}\left(\mathrm{~K}_{2} \mathrm{HPO}_{4}\right)$ at $5 \mathrm{~g} / \mathrm{L}$ concentration. This observation suggested that, although not significant to the model, the investigated variables influenced the $\beta$-galactosidase activity. It was decided to make a new regression analysis and ANOVA including only the significant independent variables. Our results confirmed that the response function $\mathrm{Y}_{1}$ decreased (data not shown), indicating that the other independent variables $\left(\mathrm{x}_{1}, \mathrm{x}_{2}, \mathrm{x}_{3}, \mathrm{x}_{6}, \mathrm{x}_{7}\right.$ and $\left.\mathrm{x}_{8}\right)$ were not in their optimal regions earlier and they were important to explain the model. The complete model can now be described as follows: $\mathrm{Y}_{1}=6.23+0.21 \mathrm{x}_{1}+3.23 \mathrm{x}_{2}+0.94 \mathrm{x}_{3}+5.58 \mathrm{x}_{4}+8.72 \mathrm{x}_{5}+3.81 \mathrm{x}_{6}+4.70 \mathrm{x}_{7}-0.55 \mathrm{x}_{8}$.

\subsection{Method of steepest ascent-descent design to investigate the maximum increase in the $\beta$-galactosidase production}

According to the results of the steepest ascent-descent design (Table 2), it was observed that assay 4 yielded maximum value for $\beta$-galactosidase activity $(39.81 \mathrm{U} / \mathrm{mL})$. This corresponds when, the concentration of independent variables sucrose $\left(\mathrm{X}_{2}\right)$ and cheese whey $\left(\mathrm{X}_{4}\right)$ were $14 \mathrm{~g} / \mathrm{L}$, yeast extract $\left(\mathrm{X}_{5}\right)$, peptone $\left(\mathrm{X}_{6}\right)$ and $\mathrm{MgSO}_{4}\left(\mathrm{X}_{7}\right)$ were $7 \mathrm{~g} / \mathrm{L}$ and lactose $\left(\mathrm{X}_{1}\right)$, glucose $\left(\mathrm{X}_{3}\right)$ and $\mathrm{K}_{2} \mathrm{HPO}_{4}\left(\mathrm{X}_{8}\right)$ were at a concentration of $10 \mathrm{~g} / \mathrm{L}, 10 \mathrm{~g} / \mathrm{L}$ and $5 \mathrm{~g} / \mathrm{L}$, respectively i.e. when present at their maximum levels. Also, the values of $\beta$-galactosidase activity were lower $(1.57 \mathrm{U} / \mathrm{mL}$ and $2.46 \mathrm{U} / \mathrm{mL}$, respectively) when the levels of independent variables decreased, as shown in assays 6 and 16. The results from the steepest ascent-descent design and from factorial design $2^{4}$ suggest that the non-significant independent variables (lactose, sucrose, glucose, peptone, $\mathrm{MgSO}_{4}$ and $\mathrm{K}_{2} \mathrm{HPO}_{4}$ ) contribute to the increase in $\beta$-galactosidase production. Therefore, to optimize the composition of fermentation medium for the $\beta$ galactosidase production and the model validation, all variables were considered.

\subsection{Rotational Central Composite Design (RCCD) $2^{4}$ to optimize the fermentation medium to the $\beta$-galactosidase production by Saccharomyces fragilis IZ 275 and model validation}

ANOVA and regression analysis were used to evaluate the effects of variables $\mathrm{X}_{1}$ (sucrose, $\mathrm{g} / \mathrm{L}$ ), $\mathrm{X}_{2}$ (whey cheese, $\mathrm{g} / \mathrm{L}$ ), $\mathrm{X}_{3}$ (yeast extract, $\mathrm{g} / \mathrm{L}$ ) and $\mathrm{X}_{4}$ (peptone, $\mathrm{g} / \mathrm{L}$ ). The linear effects of variables $X_{1}, X_{2}, X_{3}$ and $X_{4}$ were found to be significant. The quadratic effects of variables $X_{2}$ and $X_{3}$ and the interactions among the variables $X_{1} X_{2}, X_{1} X_{4}$ and $X_{2} X_{3}$ were also significant. According to Table 5 (ANOVA), the model showed a lack of fit, which was not significant ( $\mathrm{p}$ $>0.05$ ) and an $\mathrm{R}^{2}$ of 0.77 , indicating that $77 \%$ of the experimental results adequately matched the proposed model. Thus, the model can be used for predictive purposes and can be described as follows: $\mathrm{Y}_{2}=43.54+4.97 \mathrm{x}_{1}+4.69 \mathrm{x}_{2}-5.61 \mathrm{x}_{2}{ }^{2}-4.96 \mathrm{x}_{3}+4.55 \mathrm{x}_{3}{ }^{2}+2.51 \mathrm{x}_{4}-2.84 \mathrm{x}_{1} \mathrm{x}_{2}-$ $5.24 \mathrm{x}_{1} \mathrm{x}_{4}-2.66 \mathrm{x}_{2} \mathrm{x}_{3}$. 
Table 4. Factorial Design $2^{4}$ to evaluate the fermentation medium and response function $\mathrm{Y}_{1}(\beta$-galactosidase activity, U/mL).

\begin{tabular}{|c|c|c|c|c|c|c|c|c|c|}
\hline Assays & $\mathrm{X}_{1}\left(\mathrm{X}_{1}\right)$ & $\mathrm{x}_{2}\left(\mathrm{X}_{2}\right)$ & $\mathrm{x}_{3}\left(\mathrm{X}_{3}\right)$ & $\mathrm{X}_{4}\left(\mathrm{X}_{4}\right)$ & $\mathrm{X}_{5}\left(\mathrm{X}_{5}\right)$ & $\mathrm{x}_{6}\left(\mathrm{X}_{6}\right)$ & $\mathrm{X}_{7}\left(\mathrm{X}_{7}\right)$ & $\mathrm{X}_{8}\left(\mathrm{X}_{8}\right)$ & $\mathrm{Y}_{1}$ \\
\hline 1 & $-1(1)$ & $-1(1)$ & $-1(1)$ & $-1(1)$ & $-1(0.5)$ & $-1(0.5)$ & $-1(0.5)$ & $-1(0.5)$ & 1.80 \\
\hline 2 & $1(10)$ & $-1(1)$ & $-1(1)$ & $-1(1)$ & $-1(0.5)$ & $1(5)$ & $1(5)$ & $1(5)$ & 1.01 \\
\hline 3 & $-1(1)$ & $1(10)$ & $-1(1)$ & $-1(1)$ & $1(5)$ & $-1(0.5)$ & $1(5)$ & $1(5)$ & 6.22 \\
\hline 4 & $1(10)$ & $1(10)$ & $-1(1)$ & $-1(1)$ & $1(5)$ & $1(5)$ & $-1(0.5)$ & $-1(0.5)$ & 6.49 \\
\hline 5 & $-1(1)$ & $-1(1)$ & $-1(1)$ & $-1(1)$ & $1(5)$ & $1(5)$ & $1(5)$ & $-1(0.5)$ & 10.63 \\
\hline 6 & $1(10)$ & $-1(1)$ & $1(10)$ & $-1(1)$ & $1(5)$ & $-1(0.5)$ & $-1(0.5)$ & $1(5)$ & 0.20 \\
\hline 7 & $-1(1)$ & $1(10)$ & $1(10)$ & $-1(1)$ & $-1(0.5)$ & $1(5)$ & $-1(0.5)$ & $1(5)$ & 0.71 \\
\hline 8 & $1(10)$ & $1(10)$ & $1(10)$ & $-1(1)$ & $-1(0.5)$ & $-1(0.5)$ & $1(5)$ & $-1(0.5)$ & 2.25 \\
\hline 9 & $-1(1)$ & $-1(1)$ & $-1(1)$ & $1(10)$ & $1(5)$ & $1(5)$ & $-1(0.5)$ & $1(5)$ & 10.74 \\
\hline 10 & $1(10)$ & $-1(1)$ & $-1(1)$ & $1(10)$ & $1(5)$ & $-1(0.5)$ & $1(5)$ & $-1(0.5)$ & 12.51 \\
\hline 11 & $-1(1)$ & $1(10)$ & $-1(1)$ & $1(10)$ & $-1(0.5)$ & $1(5)$ & $1(5)$ & $-1(0.5)$ & 8.21 \\
\hline 12 & $1(10)$ & $1(10)$ & $-1(1)$ & $1(10)$ & $-1(0.5)$ & $-1(0.5)$ & $-1(0.5)$ & $1(5)$ & 0.92 \\
\hline 13 & $-1(1.0)$ & $-1(1)$ & $1(10)$ & $1(10)$ & $-1(0.5)$ & $-1(0.5)$ & $1(5)$ & $1(5)$ & 1.19 \\
\hline 14 & $1(10)$ & $-1(1)$ & $1(10)$ & $1(10)$ & $-1(0.5)$ & $1(5)$ & $-1(0.5)$ & $-1(0.5)$ & 0.66 \\
\hline 15 & $-1(1)$ & $1(10)$ & $1(10)$ & $1(10)$ & $1(5)$ & $-1(0.5)$ & $-1(0.5)$ & $-1(0.5)$ & 11.31 \\
\hline 16 & $1(10)$ & $1(10)$ & $1(10)$ & $1(10)$ & $1(5)$ & $1(5)$ & $1(5)$ & $1(5)$ & 28.42 \\
\hline 17 & $0(5.5)$ & $0(5.5)$ & $0(5.5)$ & $0(5.5)$ & $0(2.75)$ & $0(2.75)$ & $0(2.75)$ & $0(2.75)$ & 7.05 \\
\hline 18 & $0(5.5)$ & $0(5.5)$ & $0(5.5)$ & $0(5.5)$ & $0(2.75)$ & $0(2.75)$ & $0(2.75)$ & $0(2.75)$ & 6.89 \\
\hline 19 & $0(5.5)$ & $0(5.5)$ & $0(5.5)$ & $0(5.5)$ & $0(2.75)$ & $0(2.75)$ & $0(2.75)$ & $0(2.75)$ & 6.93 \\
\hline
\end{tabular}

Considering the complete model, the value of $\beta$-galactosidase activity was found to be $32.87 \mathrm{U} / \mathrm{mL}$, and therefore an increase of $62 \%$ in the response was obtained. 
Table 5. ANOVA for $\beta$-galactosidase activity produced by Saccharomyces fragilis IZ 275.

\begin{tabular}{cccccc}
\hline Source of variation & SS & DF & MS & F & $p$ value* \\
\hline $\mathrm{X}_{1}$ & 126.06 & 1 & 126.06 & 919.43 & $0.021^{*}$ \\
$\mathrm{X}_{1}{ }^{2}$ & 20.46 & 1 & 20.46 & 149.21 & 0.052 \\
$\mathrm{X}_{2}$ & 112.21 & 1 & 112.21 & 818.41 & $0.222^{*}$ \\
$\mathrm{X}_{2}{ }^{2}$ & 76.03 & 1 & 76.03 & 554.53 & $0.027^{*}$ \\
$\mathrm{X}_{3}$ & 125.64 & 1 & 125.64 & 916.34 & $0.021^{*}$ \\
$\mathrm{X}_{3}{ }^{2}$ & 50.11 & 1 & 50.11 & 365.49 & $0.033^{*}$ \\
$\mathrm{X}_{4}$ & 32.11 & 1 & 32.11 & 234.17 & $0.042^{*}$ \\
$\mathrm{X}_{4}{ }^{2}$ & 0.40 & 1 & 0.40 & 2.94 & 0.336 \\
$\mathrm{X}_{1} \mathrm{X}_{2}$ & 32.18 & 1 & 32.18 & 234.72 & $0.041^{*}$ \\
$\mathrm{X}_{1} \mathrm{X}_{3}$ & 7.09 & 1 & 7.09 & 51.68 & 0.088 \\
$\mathrm{X}_{1} \mathrm{X}_{4}$ & 109.68 & 1 & 109.68 & 799.98 & $0.022^{*}$ \\
$\mathrm{X}_{2} \mathrm{X}_{3}$ & 28.34 & 1 & 28.34 & 206.72 & $0.044^{*}$ \\
$\mathrm{X}_{2} \mathrm{X}_{4}$ & 0.43 & 1 & 0.43 & 3.12 & 0.328 \\
$\mathrm{X}_{3} \mathrm{X}_{4}$ & 0.19 & 1 & 0.19 & 1.39 & 0.448 \\
Lack of Fit & 215.14 & 10 & 21.51 & 156.92 & 0.062 \\
Pure Error & 0.14 & 1 & 0.14 & & \\
Total SS & 936.20 & 25 & & & \\
\hline
\end{tabular}

In Table 6 , the $\beta$-galactosidase activity in assay 21 was found to be greater $(52.84 \mathrm{U} / \mathrm{mL})$ during which the conditions were as follows: $14 \mathrm{~g} / \mathrm{L}$ sucrose, $14 \mathrm{~g} / \mathrm{L}$ cheese whey, $5.14 \mathrm{~g} / \mathrm{L}$ yeast extract and $7 \mathrm{~g} / \mathrm{L}$ peptone. Other variables (lactose, glucose, $\mathrm{MgSO}_{4}$ and $\mathrm{K}_{2} \mathrm{HPO}_{4}$ ) were stabilized at maximum levels. Assay 1 showed a lower value for $\beta$-galactosidase activity (29.62 $\mathrm{U} / \mathrm{mL}$ ), for which all variables analysed were at a minimum level, except for lactose, glucose, $\mathrm{MgSO}_{4}$ and $\mathrm{K}_{2} \mathrm{HPO}_{4}$.

After analyzing the mathematical model, response function $\mathrm{Y}_{2}$ and response surface (Figure 1a), it was observed that there was a region with maximum $\beta$-galactosidase activity when $\mathrm{x}_{1}\left(\mathrm{X}_{1}\right)$ was $-1.48(10.29 \mathrm{~g} / \mathrm{L})$ and $\mathrm{x}_{2}$ is between -1 and +1 or $\mathrm{X}_{2}$ was between 11.5 and $16.5 \mathrm{~g} / \mathrm{L}$, suggesting that the cheese whey, rich in lactose, promotes the production of enzyme by Saccharomyces fragilis IZ 275. In Figure $1 \mathrm{~b}$, there is a region in which the $\beta$-galactosidase activity is greater when $x_{1}$ and $x_{3}$ is -1.48 or $X_{1}$ is $10.29 \mathrm{~g} / \mathrm{L}$ and $x_{3}$ is $5.14 \mathrm{~g} / \mathrm{L}$. Figure $1 \mathrm{c}$ indicates two regions with maximum $\beta$-galactosidase activity when $\mathrm{x}_{1}$ is +1.48 or $17.70 \mathrm{~g} / \mathrm{L}$ and $\mathrm{x}_{4}$ is -1.48 or $5.14 \mathrm{~g} / \mathrm{L}$ and the other regions in which $\mathrm{x}_{1}$ is $-1.48(10.29 \mathrm{~g} / \mathrm{L})$ and $\mathrm{x}_{4}+1.48$ $(8.85 \mathrm{~g} / \mathrm{L})$. In Figure $1 \mathrm{~d}$, there is a region which the maximum $\beta$-galactosidase activity is observed when cheese whey, $\mathrm{x}_{2}$, ranged from 0 to 1.48 , regardless of yeast extract concentration; In Figure 1e, the maximum $\beta$-galactosidase activity is observed when the $\mathrm{x}_{2}$ ranged from 0 (center point) to +1.48 and in the Figure 1f when peptone, $\mathrm{x}_{4}$, is 1.48 or $\mathrm{X}_{4}$ is $8.85 \mathrm{~g} / \mathrm{L}$.

An assay in triplicate, which coincided with the points $\left(X_{1}=13.99 \mathrm{~g} / \mathrm{L} ; \mathrm{X}_{2}=17.7 \mathrm{~g} / \mathrm{L} ; \mathrm{X}_{3}\right.$ $=5.14 \mathrm{~g} / \mathrm{L}$ and $\mathrm{X}_{4}=8.85 \mathrm{~g} / \mathrm{L}$ ), was performed experimentally, and the result was $\mathrm{YM}$ exp. $=$ $54.68 \mathrm{U} / \mathrm{mL}$. The results, which did not differ by the t-test $(\mathrm{p}>0.05)$, confirm the validity of the proposed model. The results showed that for maximum $\beta$-galactosidase production by Saccharomyces fragilis IZ 275, the following conditions should be used: $\mathrm{X}_{1}=14 \mathrm{~g} / \mathrm{L}, \mathrm{X}_{2}=17.7$ $\mathrm{g} / \mathrm{L}, \mathrm{X}_{3}=5.14 \mathrm{~g} / \mathrm{L}, \mathrm{X}_{4}=7 \mathrm{~g} / \mathrm{L}, \mathrm{X}_{5}$ and $\mathrm{X}_{6}=10 \mathrm{~g} / \mathrm{L}, \mathrm{X}_{7}=7 \mathrm{~g} / \mathrm{L}$ and $\mathrm{X}_{8}=5 \mathrm{~g} / \mathrm{L}$ obtaining the value of $52.84 \mathrm{U} / \mathrm{mL} \beta$-galactosidase activity.

The data obtained from the present study draws attention towards two points: 1) the variables studied are critical for lactase production by Saccharomyces fragilis IZ 275; and, 2) cheese whey, a by-product of the milk and dairy industry, is an important medium for the 
growth of yeast. Thus, cheese whey could be re-used in the fermentation industry instead of being discarded as a pollutant as per the concept of the circular economy or bioeconomy (Ranta et al., 2018; López-Gómez et al., 2019). The maximum $\beta$-galactosidase activity $(28.42 \mathrm{U} / \mathrm{mL})$ obtained in factorial design was observed with $10 \mathrm{~g} / \mathrm{L}$ of lactose, sucrose, glucose and cheese whey and of variables yeast extract, peptone, $\mathrm{MgSO}_{4}$ and $\mathrm{K}_{2} \mathrm{HPO}_{4} 5 \mathrm{~g} / \mathrm{L}$. In the steepest ascentdescent design, the maximum $\beta$-galactosidase activity obtained $(39.81 \mathrm{U} / \mathrm{mL})$ for sucrose and cheese whey were $14 \mathrm{~g} / \mathrm{L}$, yeast extract, peptone and $\mathrm{MgSO}_{4}$ were $7 \mathrm{~g} / \mathrm{L}$, lactose and glucose were $10 \mathrm{~g} / \mathrm{L}$, and for $\mathrm{K}_{2} \mathrm{HPO}_{4}$ was $5 \mathrm{~g} / \mathrm{L}$. In the optimized conditions, the maximum $\beta$ galactosidase activity was $52.84 \mathrm{U} / \mathrm{mL}$ and obtained with 17.7 cheese whey, $14 \mathrm{~g} / \mathrm{L}$ of sucrose, $5.14 \mathrm{~g} / \mathrm{L}$ of yeast extract, $7 \mathrm{~g} / \mathrm{L}$ peptone and $\mathrm{MgSO}_{4}, 10 \mathrm{~g} / \mathrm{L}$ lactose and glucose and $5 \mathrm{~g} / \mathrm{L}$ $\mathrm{K}_{2} \mathrm{HPO}_{4}$. The study clearly showed that the Central Rotational Composite Design (CRCC) and Response Surface (RSM) are efficient tools to optimize the composition of fermentation medium and lactase production increased $53.78 \%$ after optimization.

Table 6. RDCC to optimize the medium fermentation to the $\beta$-galactosidase production by Saccharomyces fragilis IZ 275 and response function $\mathrm{Y}_{2}(\beta$-galactosidase activity, $\mathrm{U} / \mathrm{mL})$.

\begin{tabular}{|c|c|c|c|c|c|c|c|c|c|}
\hline Assays & $\left(\mathrm{x}_{1}\right) \mathrm{X}_{1}$ & $\left(\mathrm{x}_{2}\right) \mathrm{X}_{2}$ & $\left(\mathrm{x}_{3}\right) \mathrm{X}_{3}$ & $\left(\mathrm{x}_{4}\right) \mathrm{X}_{4}$ & Lactose & Glucose & $\mathrm{MgSO}_{4}$ & $\mathrm{~K}_{2} \mathrm{HPO}_{4}$ & $\mathrm{Y}_{2}$ \\
\hline 1 & $(-1) 11.5$ & (-1) 11.5 & (-1) 5.75 & (-1) 5.75 & 10 & 10 & 7 & 5 & 29.62 \\
\hline 2 & $(-1) 11.5$ & (-1) 11.5 & (-1) 5.75 & (1) 8.25 & 10 & 10 & 7 & 5 & 41.06 \\
\hline 3 & (-1) 11.5 & (-1) 11.5 & (1) 8.25 & (-1) 5.75 & 10 & 10 & 7 & 5 & 33.29 \\
\hline 4 & $(-1) 11.5$ & $(-1) 11.5$ & (1) 8.25 & (1) 8.25 & 10 & 10 & 7 & 5 & 35.73 \\
\hline 5 & (-1) 11.5 & (1) 16.5 & (-1) 5.75 & (-1) 5.75 & 10 & 10 & 7 & 5 & 42.89 \\
\hline 6 & $(-1) 11.5$ & (1) 16.5 & (-1) 5.75 & (1) 8.25 & 10 & 10 & 7 & 5 & 51.97 \\
\hline 7 & (-1) 11.5 & (1) 16.5 & (1) 8.25 & (-1) 5.75 & 10 & 10 & 7 & 5 & 35.47 \\
\hline 8 & (-1) 11.5 & (1) 16.5 & (1) 8.25 & (1) 8.25 & 10 & 10 & 7 & 5 & 35.91 \\
\hline 9 & (1) 16.5 & $(-1) 11.5$ & (-1) 5.75 & (-1) 5.75 & 10 & 10 & 7 & 5 & 51.09 \\
\hline 10 & (1) 16.5 & (-1) 11.5 & (-1) 5.75 & (1) 8.25 & 10 & 10 & 7 & 5 & 39.92 \\
\hline 11 & (1) 16.5 & $(-1) 11.5$ & (1) 8.25 & (-1) 5.75 & 10 & 10 & 7 & 5 & 41.23 \\
\hline 12 & (1) 16.5 & (-1) 11.5 & (1) 8.25 & (1) 8.25 & 10 & 10 & 7 & 5 & 42.28 \\
\hline 13 & (1) 16.5 & (1) 16.5 & (-1) 5.75 & (-1) 5.75 & 10 & 10 & 7 & 5 & 49.35 \\
\hline 14 & (1) 16.5 & (1) 16.5 & (-1) 5.75 & (1) 8.25 & 10 & 10 & 7 & 5 & 43.33 \\
\hline 15 & (1) 16.5 & (1) 16.5 & (1) 8.25 & (-1) 5.75 & 10 & 10 & 7 & 5 & 44.02 \\
\hline 16 & (1) 16.5 & (1) 16.5 & (1) 8.25 & (1) 8.25 & 10 & 10 & 7 & 5 & 41.67 \\
\hline 17 & 10.29 (-1.48) & (0)14 & (0) 7 & (0) 7 & 10 & 10 & 7 & 5 & 39.66 \\
\hline 18 & 17.70 (1.48) & (0)14 & (0) 7 & (0) 7 & 10 & 10 & 7 & 5 & 42.19 \\
\hline 19 & (0) 14 & $\begin{array}{c}(-1.48) \\
10.29\end{array}$ & (0) 7 & (0) 7 & 10 & 10 & 7 & 5 & 32.07 \\
\hline 20 & (0) 14 & $\begin{array}{l}(1.48) \\
17.70\end{array}$ & (0) 7 & (0) 7 & 10 & 10 & 7 & 5 & 43.85 \\
\hline 21 & (0) 14 & (0) 14 & $\begin{array}{c}(-1.48) \\
5.14\end{array}$ & (0) 7 & 10 & 10 & 7 & 5 & 52.84 \\
\hline 22 & (0) 14 & (0) 14 & $\begin{array}{c}(1.48) \\
8.85\end{array}$ & (0) 7 & 10 & 10 & 7 & 5 & 45.42 \\
\hline 23 & (0) 14 & (0) 14 & 0 & $\begin{array}{c}(-1.48) \\
5.14\end{array}$ & 10 & 10 & 7 & 5 & 36.69 \\
\hline 24 & (0)14 & (0) 14 & (0)7 & $\begin{array}{c}(1.48) \\
8.85\end{array}$ & 10 & 10 & 7 & 5 & 50.66 \\
\hline 25 & (0) 14 & (0) 14 & (0)7 & (0) 7 & 10 & 10 & 7 & 5 & 42.19 \\
\hline 26 & (0) 14 & (0) 14 & (0)7 & (0) 7 & 10 & 10 & 7 & 5 & 42.72 \\
\hline
\end{tabular}

$\mathrm{X}_{1}$ (sucrose, $\mathrm{g} / \mathrm{L}$ ); $\mathrm{X}_{2}$ (cheese whey, g/L), $\mathrm{X}_{3}$ (yeast extract, g/L), $\mathrm{X}_{4}$ (peptone, g/L). 


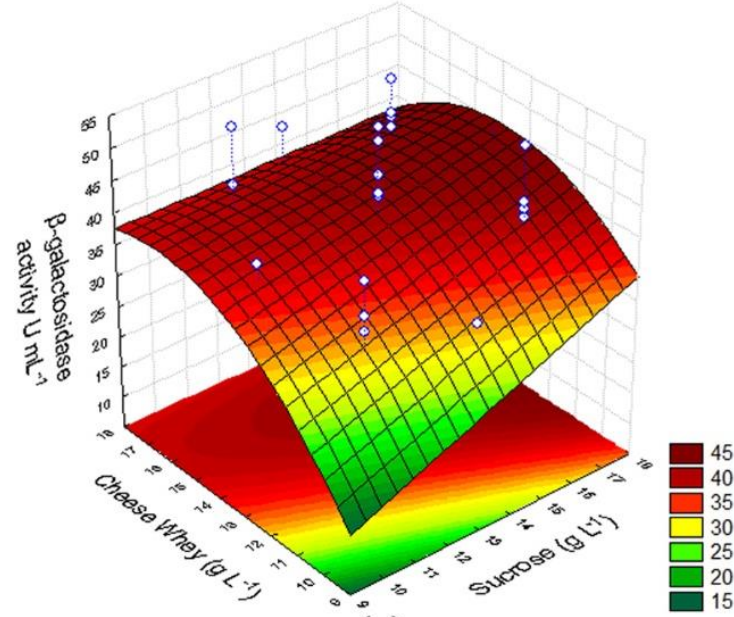

(a)

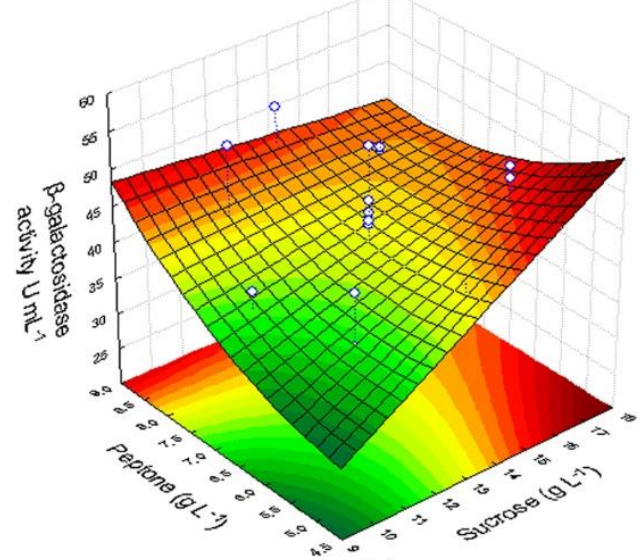

(c)



(e)

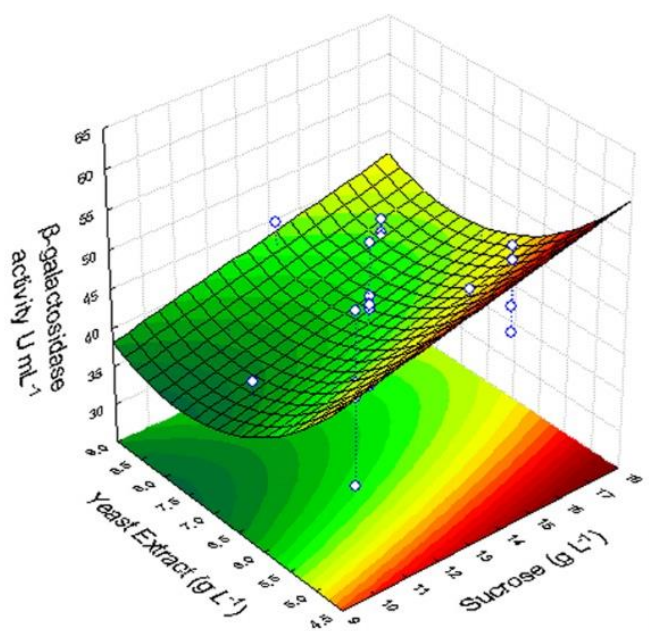

(b)

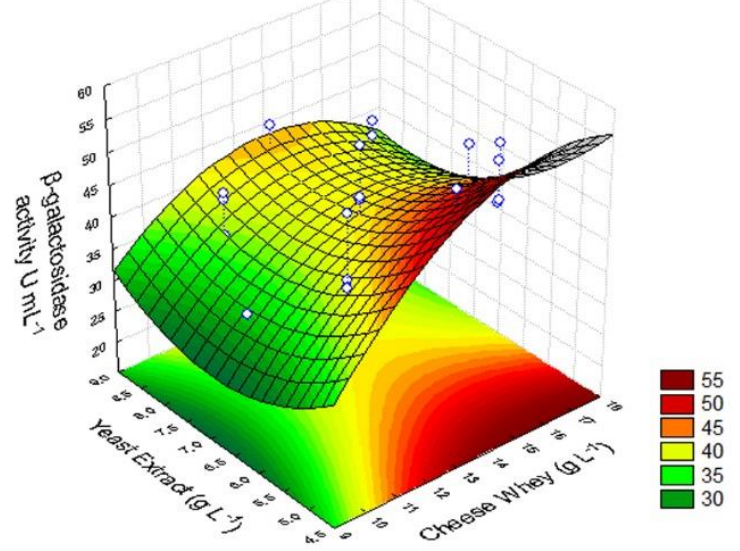

(d)

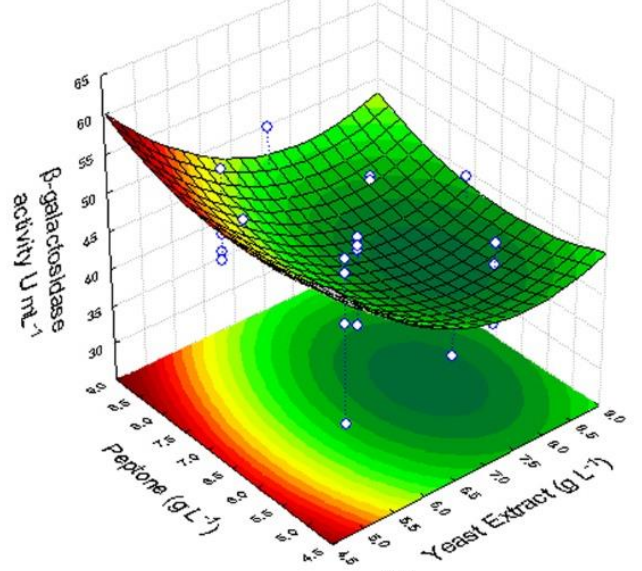

(f)

Figure 1. Response surface to $\beta$-galactosidase activity as function cheese whey and sucrose (a), sucrose and yeast extract (b); peptone and sucrose (c); cheese whey and yeast extract (d) and peptone and yeast extract (e).

It is very important to determine the composition of fermentation medium for maximum lactase production. There are few studies described in the literature that show the $\beta$ galactosidase production using different fermentations. Bosso et al. (2019) worked with microfiltrated cheese whey permeate as substrate for Saccharomyces fragilis IZ 275 yeast for the production of beta-galactosidase. Kumari et al. (2019) concluded that the use of cheese whey for $\beta$-galactosidase production improves the economics of the process, and the problems associated with its disposal. Manera et al. (2008) obtained by CRCC the maximum $\beta$ - 
galactosidase $(10.7 \mathrm{U} / \mathrm{mL})$ activity by $K$. marxianus CCT 7082 and used as fermentation medium lactose, yeast extract and $\left(\mathrm{NH}_{4}\right)_{2} \mathrm{SO}_{4}$. Venkateswarulu et al. (2017) concluded that the submerged fermentation with Bacillus subtilis strain VUVD001 produced lactase activity of 63.54 U/mL in optimized medium. The authors observed that the activity was threefold higher in comparison to an unoptimized medium and confirmed that the designed medium was useful for producing higher yields of lactase. Ahmed et al. (2016) revealed that the strain Lactobacillus $s p$. KLSA 22 isolated from cheese whey was the best potential source of lactase. Cheese whey, a dairy waste, is utilized as a carbon substrate for the enhanced enzyme production at low-cost. Obviously, the value of $\beta$-galactosidase activity can range according to microorganisms, culture conditions and fermentation medium; however, it was clear from this work that cheese whey is an excellent culture medium for Saccharomyces fragilis IZ 275 and could be employed by the food industry for $\beta$-galactosidase production. In a recent study, Murari et al. (2019) optimized bioethanol production from cheese whey using Kluyveromyces marxianus URM 7404. The authors described that cheese whey can be employed for ethanol production, reducing the environmental damages caused by this by-product.

\section{CONCLUSION}

The experimental design methodology applied in this study and the response surface are efficient tools in the optimization of fermentation medium for $\beta$-galactosidase production by Saccharomyces fragilis IZ 275. In the optimized fermentation medium, the maximum production of $\beta$-galactosidase is obtained. Cheese whey, a by-product of the dairy industry, can be employed as an excellent fermentation medium by yeast, within the bioeconomy concept and can be used by the dairy industry as a by-product with additional value.

\section{ACKNOWLEDGMENTS}

The authors thank Capes/CNPq (Conselho Nacional de Desenvolvimento Científico e Tecnológico) for financial support.

\section{REFERENCES}

AHMED, S.; LINGAPPA, K.; DIVATAR, M.; GAJARE, S.; SHIVALEE, A.; FARHEEN, A.; IRFANA, M. Optimization of Lactase Production under Submerged Fermentation by Lactobacillus sp. KLSA 22. International Journal of Pure \& Applied Bioscience, v. 4, p. 212-220, 2016.

ANISHA, G. S. $\beta$-galactosidases. In: PANDEY, A.; NEGI, S.; SOCCOL, C. R. (eds.). Current Developments in Biotechnology and Bioengineering: Production, Isolation and Purification of Industrial Products. Amsterdam: Elsevier, 2017. p. 395- 442.

BOSSO, A.; SETTI, A. C. I.; TOMAL, A. B.; GUEMRA, S.; MORIOKA, L. R. I.; SUGUIMOTO, H. H. Substrate consumption and beta-galactosidase production by Saccharomyces fragilis IZ 275 grown in cheese whey as a function of cell growth rate. $\begin{array}{llllll}\text { Biocatalysis and Agricultural Biotechnology, } & \text { v. 21, }\end{array}$ https://doi.org/10.1016/j.bcab.2019.101335

CARDOSO, B. B.; SILVÉRIO, S. C.; ABRUNHOSA, L.; TEIXEIRA, J. A.; RODRIGUES, L. R. $\beta$-galactosidase from Aspergillus lacticoffeatus: A promising biocatalyst for the synthesis of novel prebiotics. International Journal of Food Microbiology, v. 257, p. 67-74, 2017. https://doi.org/10.1016/j.ijfoodmicro.2017.06.013 
EL-TANBOLY, E.; MAHMOUD, E.; KHORSHID. Recovery of cheese whey, a by-product from the dairy industry for use as an animal feed. Journal of Nutritional Health \& Food Engineering, v. 6, n. 5, p. 148-154, 2017. https://doi.org/10.15406/jnhfe.2017.06.00215

JONES, G. K.; HOO, Y.; LEE, K. Production Technology of Lactase and Its Application in Food Industry Application. Journal of the Science of Food and Agriculture, v. 1, p. 46, 2017. https://dx.doi.org/10.26855/jsfa.2017.01.002

KARLAPUDI, A. P.; KRUPANIDHIA, S.; RAJESWARA, R. E.; INDIRA, M.; BOBBY, MD. N.; VENKATESWARULU, T. C. Plackett-Burman design for screening of process components and their effects on production of lactase by newly isolated Bacillus $s p$. VUVD101 strain from Dairy effluent. Beni-Suef University Journal of Basic Applied Sciences, v. 7, p. 543-546, 2018. https://doi.org/10.1016/j.bjbas.2018.06.006

KUMAR, M. D. J.; SUDHA, M.; DEVIKA, S.; BALAKUMARAN, M. D.; KUMAR, M. R.; KALAICHELVAN, P. T. Production and optimization of $\beta$-galactosidase by Bacillus $s p$. MPTK 121, Isolated from Dairy Plant Soil. Annals of Biological Research, v. 4, p. 1712 $1718,2012$.

KUMARI, S.; PANESAR, P. S.; KAUR, R.; BERA, M. B. Statistical modeling $\beta$-galactosidase production from novel yeast isolate using cheese whey. Journal of Scientific \& Industrial Research, v. 78, p. 81-85, 2019.

LOPES, A. C.; HIKICHI, S.; ANDRADE, R.; AMORIM, J.; DUARTE, W. New Alcoholic Fermented Beverages - Potentials and Challenges. In: GRUMEZESCU, A. M.; HOLBAN, A. M. (Eds.). Fermented Beverages. [S.1.]: Elsevier, 2018. p. 577-063. https://doi.org/10.1016/B978-0-12-815271-3.00014-2

LÓPEZ-GÓMEZ, J. P.; LATORRE-SÁNCHEZB, M.; UNGERA, P.; SCHNEIDERA, R.; LOZANOB, C. C.; VENUSA, J. Assessing the organic fraction of municipal solid wastes for the production of lactic acid. Biochemical Engineering Journal, v. 150, p. 107-251, 2019. https://doi.org/10.1016/j.bej.2019.107251

MANERA, A. P.; ORES, J. C.; RIBEIRO, V. A.; BURKERT, C. A. V.; KALIL, S. J. Optimization of the culture medium for the production of $\beta$-galactosidase from $K$. marxianus CCT 7082. Food Technology and Biotechnology, v. 46, p. 66-72, 2008.

MLICHOVÁ, Z.; ROSENBERG, M. Current trends of $\beta$-galactosidase application in food technology. Journal of Food and Nutrition Research, v. 45, p. 47-54, 2006.

MONTGOMERY, D. C. Applied statistics and probability for engineers. $3^{\text {rd }}$ ed. New Yoirk: John Wiley \& Sons, 2011.

MURARI, C. S.; MACHADO, W. R. C.; SCHUINA, G. L.; DEL BIANCHI, V. L. Optimization of bioethanol production from cheese whey using Kluyveromyces marxianus URM 7404. Biocatalysis and Agricultural Biotechnology, v. 20, p. 101-182, 2019. https://doi.org/10.1016/j.bcab.2019.101182

NATIONAL ACADEMY OF SCIENCES. Food Chemicals Codex. $4^{\text {th }}$ ed. Washington, DC: National Academy Press, 1996. p. 802-803.

PANESAR, P. S.; PANESAR, R.; SINGH, R. S.; KENNEDY, J. F.; KUMAR, H. Microbial production, immobilization and applications of $\beta$-D-galactosidase. Journal of Chemical

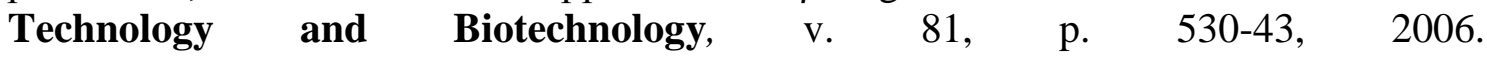
https://doi.org/10.1002/jctb.1453 
PERINI, B. L. B.; SOUZA, H. C. M.; KELBERT, M.; APATI, G. P.; PEZZIN, A. P.; SCHNEIDER, A. L. S. Optimization of Lactase Production under Submerged Fermentation by Lactobacillus sp. KLSA 22. Chemical Engineering Transactions, v. 32, p. 991-996, 2013. https://doi.org/10.3303/CET1332166

RANTA, V.; AARIKKA-STENROOS, L.; RITALA, P.; MÄKINEN, S. M. Exploring institutional drivers and barriers of the circular economy: A cross-regional comparison of China, the US, and Europe. Resources, Conservation and Recycling, v. 135, p. 70-82, 2018. https://doi.org/10.1016/j.resconrec.2017.08.017

STATSOFT INC. Statistica: data analysis software system. Version, v.7. 2007. p. 1984-2004.

VENKATESWARULU, T. C.; PRABHAKAR, K. V.; KUMAR, R. B.; KRUPANIDHI, S. Modeling and optimization of fermentation variables for enhanced production of lactase by isolated Bacillus subtilis strain VUVD001 using artificial neural networking and response surface methodology. 3 Biotech, v. 7, p. 1-7, 2017. https://doi.org/10.1007/s13205-017-0802-x

YADAV, J.; SHANKAR, S.; YAN, S.; PILLI, S.; KUMAR, L.; TYAGI, R.; SURAMPALLI, R. Cheese whey: A potential resource to transform into bioprotein, functional/nutritional proteins and bioactive peptides. Biotechnology Advances, v. 3, p. 756-774, 2015. https://doi.org/10.1016/j.biotechadv.2015.07.002 